\title{
PENGEMBANGAN INSTRUMEN MINAT BELAJAR SISWA PADA PELAJARAN MATEMATIKA
}

\author{
Dwi Dani Apriyani ${ }^{1}$, Erlando Doni Sirait ${ }^{2}$ \\ Program Studi Teknik Informatika, Universitas Indraprasta PGRI ${ }^{1,2}$ \\ Email: dwidani12@gmail.com
}

\begin{abstract}
Abstrak
Seringnya siswa merasa kesulitan dan kurang berminat pada pelajaran matematika, maka perlu dilakukan uji minat belajar siswa. Tujuan penelitian ini adalah untuk mengetahui tingkat valid dan reliabelnya suatu kuesioner minat belajar. Penelitian ini dilakukan dengan metode Research and Development. Kuesioner minat belajar siswa pada matematika dapat diberikan kepada siswa jika sudah diuji validitas dan reliabilitas. Pada penelitian ini dilakukan uji validitas dengan rumus korelasi product moment. Uji reliabilitas dilakukan dengan rumus koefisien Alpha Cronbach. Penelitian ini dilakukan pada sampel sebanyak 89 siswa kelas VIII SMP Negeri 7 Depok dan SMP Negeri 12 Depok. Dari hasil uji validitas didapatkan 27 soal valid dan 3 soal tidak valid, sehingga tidak digunakan. Kemudian mendapatkan hasil uji reliabilitas yaitu 0,752 , hasil tersebut lebih dari 0,70 yang berarti bahwa kuesioner tersebut reliabel. Dari hasil uji validitas dan reliabilitas dapat disimpulkan bahwa kuesioner pada penelitian ini dapat digunakan untuk penelitian selanjutnya.
\end{abstract}

Kata Kunci : Instrumen, Minat Belajar Siswa, Matematika

\begin{abstract}
Students often find difficult and less interested in mathematics, thus it is necessary to test students learning interests. The purpose of this study is to determine the level of validity and reliability of a learning interests questionnaire. Students' interest in mathematics questionnaires can be given to students if their validity and reliability have been tested. In this study, the validity test was carried out with the product-moment correlation formula. The reliability test was carried out with the Cronbach Alpha coefficient formula. This research was conducted on a sample of 89 students of class VIII SMPN 7 Depok. Based on the results of the validity test, it was found that 27 questions were valid and 3 questions were invalid so they were eliminated. Then the reliability test results were 0.752, which was more than 0.70, indicating that the questionnaire was reliable. From the results of the validity and reliability tests, it can be concluded that the questionnaire in this study can be used for further research.
\end{abstract}

Key Words : Instruments, Student Learning Interests, Mathematics

\section{PENDAHULUAN}

Kehidupan sehari-hari tidak luput dari penggunaan matematika. Dimulai dari hal yang paling sederhana kita sudah mengaplikasikan matematika. Matematika mengajarkan cara berpikir serta bernalar dengan ilmu. Menggunakan matematika dalam kehidupan sehari-hari mengajarkan bagaimana cara menghadapi masalah dan keinginan untuk belajar [1]. Berpikir dan bernalar yang terarah akan meningkatkan disiplin pada pribadi seseorang. Maka tak heran jika matematika dikatakan sebagai mata pelajaran yang mampu meningkatkan kemampuan berpikir dan beragumentasi serta menjadi disiplin ilmu [2]. Sejak jenjang sekolah dasar hingga sekolah menengah atas, matematika adalah mata pelajaran penting yang harus dipelajari oleh siswa. Dikarenakan matematika merupakan ilmu yang memegang andil tinggi pada dunia pendidikan [3].

Sering kali guru menghadapi tinggi dan rendahnya minat belajar siswa pada matematika. Hal tersebut dikarenakan siswa merasa bahwa pelajaran matematika salah satu pelajaran yang menakutkan [4]. Minat belajar siswa terlihat dari adanya dorongan seseorang yang sedang belajar memiliki dorongan kuat dan perhatian pada apa yang sedang dipelajarinya. Minat pada 
pelajaran yang sedang dilaksanakan akan berdampak pada pencapaian prestasi siswa. Minat dari pribadi siswa akan mempengaruhi hal di luar diri siswa seperti prestasi. Karena berdampak pada prestasi, maka perlu dibangkitkannya minat siswa untuk belajar lebih keras. Dapat dikatakan bahwa minat belajar adalah rasa ketertarikan, perhatian, rasa berjuang, dan faktor pendorong seseorang dalam melakukan sesuatu [5]. Jika terdapat siswa yang berminat belajar matematika akan ditandai dengan belajar sungguh-sungguh seperti rajin mengulang materi sendirinya, merasa senang mengikuti pelajaran matematika dan jika mengalami kesulitan dalam menyelesaikan soal-soal siswa tersebut tidak kehilangan daya tariknya.

Untuk menguji besar kecilnya minat siswa terhadap mata pelajaran matematika perlu adanya pengujian tingkat minat belajar siswa. Jika bahan pelajaran yang dipelajari tidak sesuai dengan minat siswa maka siswa tidak tertarik dan siswa tersebut tidak akan tergerak untuk tekun belajar dan tidak akan belajar dengan baik. Sedangkan bila bahan pelajaran itu menarik minat siswa, maka ia akan mudah dipelajari dan disimpan karena adanya minat sehingga adanya dorongan untuk terus belajar dan menambah kegiatan belajar. Minat yang merupakan sesuatu dalam perilaku seseorang dalam melakukan kegiatan dengan baik senantiasa menaruh perhatian dan merelakan dirinya untuk terikat pada kegiatan tersebut, kesukaan terhadap suatu kegiatan akan melebihi kegiatan lainnya dikarenakan rasa suka dan diekspresikan dalam tindakan.

Menguji tingkat minat belajar siswa perlu dibuatnya instrumen yang kemudian dijadikan kuesioner. Instrumen dibuat dengan cara menyusun indikator atau kisikisi berdasarkan teori penelitian dan dilakukan sesuai prosedur [6]. Instrumen dikatakan juga sebagai alat bantu yang digunakan untuk mengumpulkan data sehingga memudahkan dalam penentuan hasil dan mendapatkan hasil yang cepat, akurat dan sistematis [7]. Instrumen merupakan alat yang dibuat dalam bentuk pertanyaan atau pernyataan secara tertulis pada responden disebut sebagai kuesioner [8]. Instrumen yang sudah dibuat sesuai dengan metode dan prosedurnya dapat diberikan kepada siswa dan kemudian diolah. Instrumen yang sudah diolah akan memberikan hasil mengenai tanggapan minat siswa dalam mengikuti pelajaran matematika [9]. Instrumen dalam bentuk pertanyaan dan sudah disediakan jawabannya dapat dikatakan sebagai kuisioner tertutup [10]. Dengan memberikan kuesioner kepada siswa maka peneliti dapat langsung memperoleh jawaban dari responden atau siswa [11].

Penelitian dilakukan dengan mengembangkan instrumen minat belajar siswa pada mata pelajaran matematika yang bertujuan untuk mengetahui sejauh mana minat belajar siswa, serta menghasilkan instrumen minat belajar siswa yang valid dan reliabel. Kegunaan kuesioner ini dapat dimanfaatkan oleh peneliti lain yang juga ingin mengetahui minat belajar siswa pada responden yang berbeda. Tidak terkecuali dalam situasi pandemi COVID 19 saat ini. Efek dari penyebaran virus COVID-19 yang mengharuskan pembelajaran dilakukan secara daring, sehingga siswa tidak dapat terlihat dan terpantau secara langsung oleh guru. Dengan kuesioner minat belajar siswa, guru dapat mengetahui apakah para siswa masih bersemangat dan berminat pada pembelajaran yang dilakukan.

\section{METODE}

Penelitian ini dilakukan di SMP Negeri 7 Depok dan SMP Negeri 12 Depok yang dilaksanakan pada semester genap tahun ajaran 2015/ 2016 pada siswa kelas VIII dengan jumlah sampel 89 siswa. Penelitian 
ini dilakukan dengan metode Research and Development.

Teknik pengumpulan data minat belajar dilakukan dengan cara memberikan angket kepada siswa sebanyak 30 butir soal dengan skala Likert yang pengukurannya dimulai dengan skor 1 hingga 5 dan aspek penilaian selalu, sering, kadang-kadang, jarang, dan tidak pernah seperti yang tertera pada Tabel berikut:

Tabel 1. Kategori Penilaian Angket

\begin{tabular}{cccc}
\hline ASPEK & KETERANGAN & \multicolumn{2}{c}{ SKOR } \\
& & PERTANYAAN \\
\hline Penilaian & & 5 & 1 \\
SL & Selalu & 4 & 2 \\
SR & Sering & 3 & 3 \\
KD & Kadang-kadang & 2 & 4 \\
J & Jarang & 1 & 5 \\
TP & Tidak Pernah & 1 & Negatif \\
\hline
\end{tabular}

Kuesioner minat belajar siswa akan dilakukan uji coba instrumen dengan uji validitas dan uji reliabilitas. Uji validitas dilakukan dengan rumus korelasi product moment. Uji reliabilitas dilakukan dengan rumus koefisien Alpha Cronbach.

\section{HASIL DAN PEMBAHASAN}

Kuesioner minat belajar siswa berjumlah 30 soal dengan indikator instrumen sebagai berikut

\section{Tabel 2. Indikator Kuesioner}

\begin{tabular}{cll}
\hline No & \multicolumn{1}{c}{ Indikator } & No soal \\
\hline 1 & $\begin{array}{l}\text { Memiliki inisiatif untuk } \\
\text { belajar matematika }\end{array}$ & $1,2,18$ \\
2 & $\begin{array}{l}\text { Belajar dengan sungguh- } \\
\text { sungguh }\end{array}$ & 3,19 \\
3 & $\begin{array}{l}\text { Memiliki alat-alat dan buku } \\
\text { pelajaran matematika }\end{array}$ & $4,5,6,20$ \\
4 & Mengerjakan tugas tepat & 7.21 \\
& waktu & \\
5 & Aktif bertanya jika pelajaran & 8,9 \\
& kurang dipahami & 10,11, \\
6 & Melatih diri menjawab soal- & $22,23,24$ \\
& soal matematika & $12,13,14$ \\
7 & Rasa ingin tahu &, 27 \\
& Memiliki jadwal belajar & 15,28 \\
9 & Memiliki manfaat dalam & 16,17, \\
& kehidupan sehari-hari & 29,30 \\
10 & Memiliki target nilai & 25,26 \\
\hline
\end{tabular}

Selanjutnya kuesioner yang telah diberi tanggapan oleh siswa dilakukan pengujian. Pengujian validitas dimaksudkan untuk mengetahui sejauh mana alat ukur dapat mengukur secara tepat apa yang akan diukur. Pengujian validitas angket menggunakan rumus korelasi product moment. Untuk memberikan interpretasi terhadap koefisien validitas terlebih dahulu mencari $d k$ (derajat kepercayaan) $=n-2$, dimana $n$ adalah jumlah responden yang pada penelitian ini berjumlah 30 , maka $d k$ $($ derajat kepercayaan $)=30-2=28$ sehingga nilai $r_{\text {tabel }}$ untuk taraf signifikan $\alpha=0,05$ dan $d k=28$ yaitu 0,361 . Hasil perhitungan uji validitas pada kuesioner tertera pada Tabel 3.

Tabel 3. Perhitungan Uji Validitas

\begin{tabular}{ccc}
\hline No Soal & R Hitung & Keterangan \\
\hline 1 & 0,412 & Valid \\
2 & $-0,046$ & Tidak Valid \\
3 & 0,436 & Valid \\
4 & 0,422 & Valid \\
5 & $-0,299$ & Tidak Valid \\
6 & 0,450 & Valid \\
7 & 0,671 & Valid \\
8 & 0,393 & Valid \\
9 & 0,527 & Valid \\
10 & 0,516 & Valid \\
11 & 0,417 & Valid \\
12 & 0,412 & Valid \\
13 & 0,416 & Valid \\
14 & 0,394 & Valid \\
15 & 0,475 & Valid \\
16 & 0,427 & Valid \\
17 & 0,392 & Valid \\
18 & 0,623 & Valid \\
19 & 0,376 & Valid \\
20 & 0,380 & Valid \\
21 & 0,397 & Valid \\
22 & $-0,039$ & Tidak Valid \\
23 & 0,382 & Valid \\
24 & 0,595 & Valid \\
25 & 0,537 & Valid \\
26 & 0,519 & Valid \\
27 & 0,407 & Valid \\
28 & 0,363 & Valid \\
29 & 0,429 & Valid \\
30 & 0,501 & Valid \\
\hline
\end{tabular}

Dari data di atas, diperoleh 3 soal memenuhi kriteria $r_{\text {hitung }}<r_{\text {tabel }}$, dengan 
kata lain soal tersebut tidak valid, yaitu soal nomor 2 dengan $r_{\text {hitung }}=-0,046$, soal nomor 5 dengan $r_{\text {hitung }}=-0,299$ dan soal nomor 22 memiliki $r_{\text {hitung }}=-0.039$. Sedangkan 27 soal lainnya memenuhi kriteria pengujian validitas butir soal $r_{\text {hitung }}$ $\geq r_{\text {tabel }}$ dengan kata lain soal tersebut valid dan dapat digunakan dalam penelitian.

Selanjutnya dilakukan uji reliabilitas. Uji reliabilitas melihat sejauhmana hasil suatu pengukuran dapat dipercaya. Hasil pengukuran dapat dipercaya jika dalam beberapa pelaksanaan pengukuran terhadap kelompok subjek yang sama akan diperoleh hasil yang sama, selama aspek yang diukur dalam diri subjek memang belum berubah. Untuk menghitung reliabilitas pada tes dalam bentuk uraian atau skala yang pengukurannya tidak hanya skor benar $=1$ dan skor salah $=0$ digunakan rumus koefisien Alpha Cronbach. Interpretasi koefisien reliabilitas tes $\left(r_{11}\right)$ dinyatakan sebagai berikut: Jika $r_{11} \geq 0,70$ berarti tes yang sedang diuji memiliki reliabilitas yang tinggi. Jika $r_{11}<0,70$ berarti tes yang sedang diuji reliabilitasnya dinyatakan memiliki reliabilitas yang rendah (unreliable). Kuesioner di atas setelah diolah data memperoleh $r_{11}=0,829$ yang berarti $r_{11} \geq 0,70$ maka instrumen memiliki reliabilitas tinggi atau reliabel.

Berikut ini adalah pernyataan kuesioner yang diberikan kepada siswa dan telah memiliki hasil yang valid dan reliabel :

\section{Tabel 4. Kuesioner Minat Belajar Siswa}

\begin{aligned} & \hline \multicolumn{1}{c}{ PERNYATAAN } \\ & \hline 1 Saya belajar tanpa disuruh oleh orang lain. \\ & 2 Saya mengerjakan tugas matematika yang diberikan guru dengan sungguh-sungguh. \\ & 3 Saya tertarik membeli buku pelajaran matematika dibandingkan novel atau komik. \\ & 4 Saya memiliki buku catatan dan buku latihan khusus matematika. \\ & 5 Saya biasa mengerjakan PR tepat waktu. \\ & 6 Saya akan bertanya bila pelajaran kurang dipahami. \\ & 7 Jika saya menemukan soal yang sulit dipahami, maka saya akan bertanya pada guru. \\ & 8 Saya mencari soal latihan pelajaran matematika dibanyak buku. \\ & 9 Saya mengerjakan sendiri soal-soal latihan matematika. \\ & 10 Mata pelajaran matematika sangat menarik buat saya. \\ & 11 Saya membaca materi pelajaran matematika yang akan dipelajari esok pagi, semalam sebelumnya. \\ & 12 Saya senang mempelajari rumus-rumus matematika yang baru saya ketahui. \\ & 13 Saya memiliki dan mematuhi jadwal belajar yang telah saya buat. \\ & 14 Jika ada teman yang mengalami kesulitan memahami pelajaran matematika, maka saya akan \\ & membantunya memahami pelajaran matematika. \\ & 15 Saya menggunakan rumus matematika dalam kehidupan sehari-hari. \\ & 16 Saya tidak mencatat materi yang diajarkan guru di papan tulis. \\ & 17 Saya belajar matematika sambil menonton televisi. \\ & 18 Saya tidak pernah membawa buku pelajaran matematika ke sekolah. \\ & 19 Saya mengerjakan PR matematika di sekolah. \\ & 20 Jika saya menemui soal yang tidak bisa saya jawab, maka saya akan menyerah. \\ & 21 Saya putus asa jika dihadapkan dengan soal matematika. \\ & 22 Kunci keberhasilan dalam ulangan matematika adalah belajar dengan sungguh-sungguh dan \\ & mengandalkan teman. \\ & 23 Sudah cukup bagi saya jika nilai saya hanya mencapai KKM. \\ & 24 Ketika saya salah menjawab soal matematika, saya akan berhenti mempelajarinya. \\ & 26 Saya belajar ketika kondisi saya baik saja. \\ & 27 Matematika tidak memiliki kegunaan dalam kehidupan sehari-hari. \\ & \hline\end{aligned}


Dari hasil perhitungan uji validitas dan uji reliabilitas, maka kuesioner minat belajar siswa layak digunakan pada siswa SMP dan dapat membantu penelitian. Kecenderungan yang positif, sehingga dapat membantu diri untuk melakukan sesuatu hal dan mendorong diri membangkitkan kesenangan ialah minat belajar siswa [12]. Minat belajar mempunyai pengaruh yang besar dalam kegiatan belajar.

Terkait dengan kondisi pandemi COVID19 yang mengharuskan pembelajaran dilakukan menggunakan aplikasi virtual yang terkoneksi internet. Para orang tua dan siswa secara tidak langsung diharuskan mampu mengikuti pembelajaran secara daring [13]. Pada proses pembelajaran daring, siswa diberikan menyaksikan video pembelajaran dan melaksanakan pembelajaran di rumah masing-masing. Hal tersebut dapat berpengaruh pada minat belajar siswa [14]. Keterbatasan interaksi guru yang tidak dapat memantau dan bertemu langsung dengan siswa tetap mengharuskan guru melakukan evaluasi pada siswa [15]. Oleh karena itu, kuesioner minat belajar ini dapat membantu guru melakukan evaluasi minat belajar pada siswa.

\section{SIMPULAN}

Penelitian dapat menggunakan kuesioner atau angket sebagai alat ukur. Pada variabel minat belajar siswa dapat dilakukan kuesioner minat belajar siswa yang telah diuji validitas dan reliabilitasnya. Pada penelitian ini telah didapatkan kuesioner minat belajar siswa sebanyak 27 soal yang valid dan reliable, sehingga kuesioner minat belajar siswa dapat diisi serta digunakan untuk kemudian hari.

\section{DAFTAR PUSTAKA}

[1] I. Monicca C, Subkhan, dan R. Setiyani, "Pengaruh Minat Belajar,
Motivasi Belajar dan Prestasi Belajar Matematika terhadap Prestasi Belajar Akuntansi Siswa Kelas X Jurusan Akuntansi di SMK Palebon Semarang," Economic Education Analysis Journal, vol. 4, no. 2, pp. 414-426, 2015.

[2] S. H. Sholehah, D. E. Handayani, dan S. A. Prasetyo, "Minat Belajar Siswa pada Mata Pelajaran Matematika Kelas IV SD Negeri Karangroto 04 Semarang," Mimb. Ilmu, vol. 23, no. 3, pp. 237-244, 2018.

[3] A. W. Putri dan R. Nuraida, "Analisis Kesulitan Siswa dalam Mengerjakan Soal Cerita Aritmatika Sosial Ditinjau Berdasarkan Gender," Jurnal Pendidikan Matematika, vol. 8, no. 4, pp. 289298, 2020.

[4] E. D. Sirait, "Pengaruh Minat Belajar terhadap Prestasi Belajar Matematika," Form. J. Ilm. Pendidik. MIPA, vol. 6, no. 1, pp. 35-43, 2016.

[5] S. Nurhasanah dan A. Sobandi, "Minat Belajar sebagai Determinan Hasil Belajar Siswa," J. Pendidik. Manaj. Perkantoran, vol. 1, no. 1, p. 128, 2016.

[6] H. S. Adib, "Teknik Pengembangan Instrumen Penelitian Ilmiah di Perguruan Tinggi Keagamaan Islam," Sains Dan Teknoogi, pp. 139-157, 2015.

[7] J. H. Hatmoko, "Survei Minat dan Motivasi Siswa Putri terhadap Mata Pelajaran Penjasorkes di SMK SeKota Salatiga Tahun 2013," E-Jurnal Physical Education, Sport, Health and Recreation, vol. 4, no. 4, pp. 1729-1736, 2015.

[8] P. Purnomo dan M. S. Palupi, "Pengembangan Tes Hasil Belajar Matematika Materi Menyelesaikan Masalah yang Berkaitan dengan Waktu, Jarak dan Kecepatan untuk Siswa Kelas V," J. Penelit. (Edisi 
Khusus PGSD), vol. 20, no. 2, pp. 151-157, 2016.

[9] Z. Abidin dan S. Purbawanto, "Pemahaman Siswa terhadap Pemanfaatan Media Pembelajaran Berbasis Livewire pada Mata Pelajaran Teknik Listrik Kelas X Jurusan Audio Video di SMK Negeri 4 Semarang," Edu Elektrika, vol. 4, no. 1, pp. 38-49, 2015.

[10] D. Damayanti, "Sihapes (Sistem Informasi Hasil Penilaian Siswa) bagi Sekolah Menengah Pertama di SMP Negeri 7 Semarang," $E d u$ Komputika Journal, vol. 1, no. 2, pp. 52-62, 2014.

[11] L. Y. Kurnianingtyas dan M. A. Nugroho, "Implementasi Strategi Pembelajaran Kooperatif Teknik Jigsaw untuk Meningkatkan Keaktifan Belajar Akuntansi pada Siswa Kelas X Akuntansi 3 SMK Negeri 7 Yogyakarta Tahun Ajaran 2011/2012," J. Pendidik. Akunt. Indones., vol. 10, no. 1, pp. 66-77, 2012.

[12] Reflinda, "The Effect of Learning
Strategy and Reading Interest to the Reading Understanding Ability of Students of Iain Bukit Tinggi," Int. J. Lang. , Res. Educ. Stud., vol. 1, no. 2, pp. 226-239, 2017.

[13] M. Marwa, M. Munirah, A. D. Angriani, S. Suharti, A. Sriyanti, dan R. Rosdiana, "Peran Guru dalam Meningkatkan Minat Belajar Peserta Didik Kelas IV pada Masa Pandemi COVID-19," AULADUNA J. Pendidik. Dasar Islam, vol. 7, no. 2, p. 215, 2020.

[14] R. R. Dalimunthe, R. D. Harahap, dan D. A. Harahap, "Analisis Minat Belajar Siswa Sekolah Dasar terhadap Mata Pelajaran IPA pada Masa Pandemi COVID-19," J. basicedu, vol. 3, no. 2, pp. 524-532, 2020.

[15] R. Yunitasari dan U. Hanifah, "Pengaruh Pembelajaran Daring terhadap Minat Belajar Siswa pada Masa COVID 19," Edukatif J. Ilmu Pendidik., vol. 2, no. 3, pp. 232-243, 2020. 